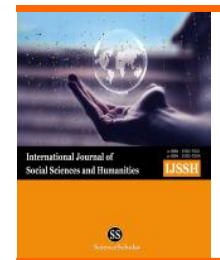

International Journal of Social Sciences and Humanities

Available online at http://sciencescholar.us/journal/index.php/ijssh

Vol. 1 No. 2, August 2017, pages: 20 28

e-ISSN: 2550-7001, p-ISSN: 2550-701X

http://dx.doi.org/10.21744/ijssh.v1i2.32

\title{
The Role of Tourism Stakeholders at Jasri Tourism Village Development, Karangasem Regency
}

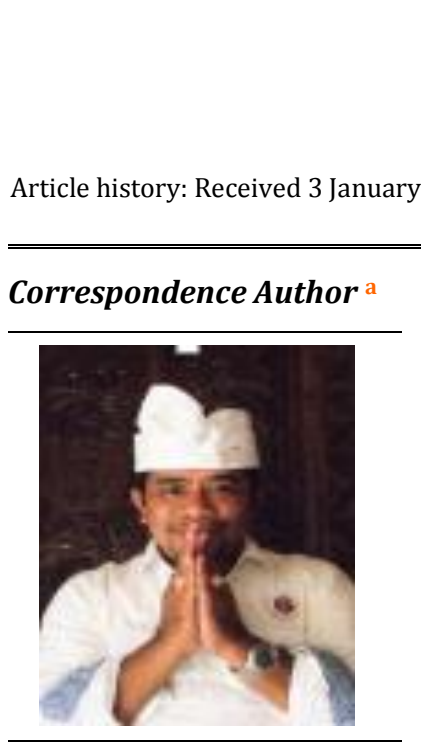

Keywords

Asri tourism village;

Community-based;

Tourism development;

Tourism stakeholders;

Tourist destination;

$\underset{\text { CrossMark }}{\text { Clidtorupdaces }}$

I Made Suniastha Amerta ${ }^{a}$

; Accepted in revised form 7 July 2017; Approved 20 July 2017; Available online 31 August 2017

\begin{abstract}
The success on the development of tourism in a tourist destination depends on the role/participation of tourism stakeholders in the area. Similarly, in the development of rural tourism in the Pakraman Jasri Village. Since the beginning or the planning of tourism development in this village until the time of its development, the tourism stakeholders, namely the local community, government, and investors in this village have been actively and directly involved in supporting the development of Jasri Tourism Village. This writing aims at knowing and understanding the role of tourism stakeholders in Jasri Tourism Village which considered have played the important role in developing tourism in the village. This research was conducted by using the qualitative method in accordance with the rules of scientific research and the paradigm of Cultural Studies. The result of the study showed that the role of tourism stakeholders can be seen in the early planning of Jasri Tourism Village and in the development of Jasri Tourism Village. The tourism stakeholders at Jasri Village have done some efforts to make sure that the development of Jasri Tourism Village will be a success and able to give a significant impact, particularly in improving the welfare of the local society of the Pakraman Village of Jasri in the future time.
\end{abstract}

e-ISSN : 2550-7001, p-ISSN : 2550-701X@ Copyright 2017. The Author. SS Journals Published by Universidad Técnica de Manabí. This is an open-access article under the CC BY-SA 4.0 license (https://creativecommons.org/licenses/by-sa/4.0/) All rights reserved.

a Faculty of Economics, Management Studies Program, Warmadewa University, Denpasar, Bali - Indonesia Ph. (0361) 223858, Email address: jrokadek@yahoo.co.id 


\section{Contents}

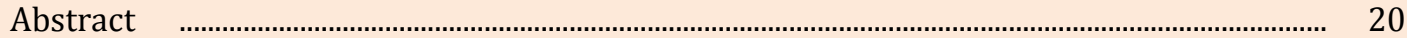

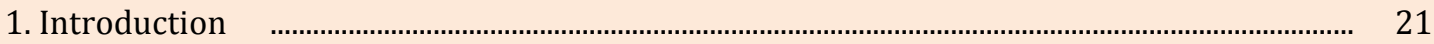

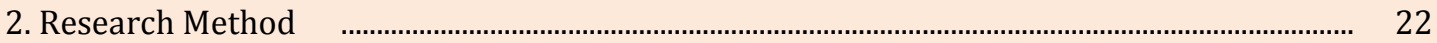

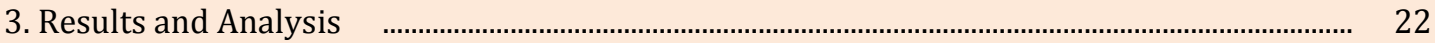

The Role of the Local Community of Jasri Village .............................................................................. $\quad 22$

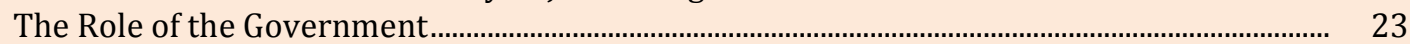

The Role of the Tourism Actors (investors) ……………………………………….......................... 24

4. Conclusions

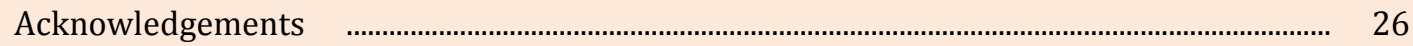

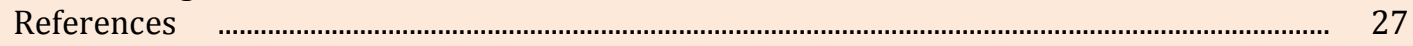

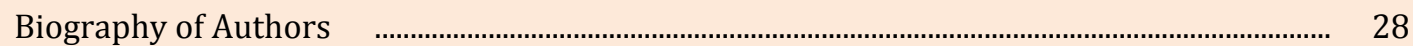

\section{Introduction}

Karangasem regency is one of nine regencies/municipalities in Bali Province which is geographically located in the eastern tip of Bali. The Regency has a variety of tourism potential, particularly for the development of cultural tourism and nature tourism, which should be explored and promoted as a capital of tourism development in this regency in the near future.

The beauty of natural scenery and traditional culture in the Karangasem Regency is filled with unique local customs that can be seen in every activity of the major Hinduism rituals, like Usaba Sembah and Mekaré-kare with pandanus war in the village of Tenganan, Usaba Dangsil at the Village of Bungaya, Usaba Dodol in the Selat Village, Gebug Ende in the Village of Seraya (Karangasem Tourism Office, 2013). Some of the natural and cultural potentials of Karangasem have been explored and developed as the alternative tourism development, such as spiritual tourism, ecotourism, agrotourism, and tourism village.

Tourism village defines as a rural area which offers a whole atmosphere reflects the countryside authenticity, either layout, the architecture of the building, as well as the pattern of social and cultural life of society, customs of everyday life (Suwantoro, 1997). It is able to provide components of the basic needs of travelers, such as accommodation, food and drinks, souvenirs and tourist attractions. Moreover, Inskeep (1991) defines village tourism, where small groups of tourist stay in or near traditional, often remote villages and learn about village life and the local environment. He stated that a tourism village as a development of village area by utilizing various potentials and capabilities of the elements that exist in rural communities that serve as attributes of tourism products, into a series of integrated tourism activities.

The development of tourism village of Jasri has fully involved the local community in the area of Pakraman Jasri Village. The success of Pakraman Jasri Village development as a tourism village at the beginning was inseparable from the role of the local governments through the assistance of Karangasem Regency PNPM program in the field of tourism.

Various achievements have been made by the Tourism Village of Jasri. The village acquired the pinnacle of achievement in the national level competition of tourism villages in 2013. In that competition, the Tourism Village of Jasri was able to demonstrate its peak performance to get the first national winner. The achievement made the Tourism Village of Jasri as the host of the Tourism Village Award and the Creative Economy of national level in 2014. The event was held at the Hall of Banjar of the Pakraman Village of Jasri. At the time, the Minister of Tourism and Creative Economy, Mary Elka Pangestu also attended and visited this village.

The phenomenal glorious achievements in the field of tourism achieved by the Pakraman Village of Jasri is not worth with the effects given by the tourism sector, i.e. the welfare of the people in this village. To find out and understand the role of the tourism stakeholders which have totally involved in the development of alternative tourism in Pakraman Jasri Village since the process of planning until the current development, it is necessary to conduct the study which uses the perspective of critical, emancipatory and participative of cultural studies.

Suniastha Amerta, I. M. (2017). The role of tourism stakeholders at Jasri tourism village development, Karangasem regency. International Journal of Social Sciences and Humanities, 1(2), 20-28. https://doi.org/10.29332/ijssh.v1n2.32 


\section{Research Method}

The research was conducted by the qualitative method. The method was used to get such deeper data containing meanings and considered as the real and valuable certain appeared data (Sugiyono, 2008:222). The selection of this approach was based on the problems and objectives of research as well as the analysis techniques, which was used to enable the research process to be carried out appropriately. The research uses qualitative data supported by quantitative data. On the other hand, the data used were primary and secondary data sources. The data collection techniques were carried out in various ways, namely observation, interview, documentation, and library research.

The study was conducted in the Pakraman Village of Jasri, Subagan Administrative Village, Karangasem Sub-district, Karangasem Regency, Bali Province. The village has already been established as one of the tourism villages by the Karangasem Regent Decree number 658 / HK / 2014.

The collected data which related to the role of the stakeholders of tourism at Pakraman Jasri Village were analyzed by using qualitative analysis in the perspective of cultural studies. Presentation of the results of the data analysis is the last stage of the whole process of research conducted in accordance with the problems and research objectives. According to Sudikan (2001: 121-122), results of data analysis are presented in such a manner and holistic-integrated so as to produce a conclusion on the subject being studied.

However, in conducting this study, some relevant research results and writings were used to support the research. They are: (1) a research of Maribeth Erb (2005) entitled Limiting Tourism and the Limits of Tourism: The Production and Consumption of Tourist Attraction in Western Flores is interesting to be observed (this research examined the issue of local production and consumption of tourist attractions in a small town of Labuan Bajo, Manggarai Regency, Western Flores); (2) "Participation of Local Communities for the Development of the Nusa Dua Tourism (Perspective of Cultural Studies" by Madiun (2008); and (3) the results of research conducted by Pitana et al. (2000) on "The Carrying Capacity of Bali in Tourism (Assessment of Environmental and Social Aspects of Culture)".

\section{Results and Analysis}

In this section, the writer presents the role of tourism stakeholders of Jasri Tourism Village in two stages, they are: (1) the role of the tourism stakeholders in the early planning of Jasri Tourism Village; and (2) the role of the tourism stakeholders in the development of the Tourism Village of Jasri. Those tourism stakeholders of Jasri Village are the local community of Jasri Pakraman Village, the government, and the investors (tourism actors).

\subsection{The Role of the Local Community of Jasri Village}

The development of rural tourism is synonymous with the development of community-based tourism by utilizing the potential of local wisdom, small-scale, environmentally friendly, and can provide benefits to society, both economically, socially, and culturally. The local community as one of the tourism stakeholders has a very important role either in the early planning or in the development of Jasri Tourism Village.

\subsubsection{The Role of the Local Community in the Early Planning of Jasri Tourism Village}

Since the beginning of tourism development planning in Jasri Village which was started in 2009 , the role of the local community was very immense. When they heard of tourism development discourse in their village, the people felt happy, enthusiastic, and very supportive. Evidently, in every socialization was held, either by officers from the Department of Culture and Tourism (Disbudpar) Karangasem regency or by the administrators of Pakraman Jasri Village, the local community always followed the meeting seriously and full of enthusiasm.

The existence of information about the planning of development of tourism sector in the village of Jasri, the local community expectation was very high and they were very optimistic to 
welcome the plan. This was conveyed by I Ketut Kertia (62 years old), one of the informants who was a local community leader and daily was a treasurer of Pakraman Jasri Village.

\begin{abstract}
"sejak awal penyampaian informasi mengenai perencanaan pengusulan pembangunan pariwisata di Desa Pakraman Jasri oleh pengurus Desa Pakraman Jasri, masyarakat sangat senang dan menyambut ide tersebut dengan penuh antusias. Masyarakat kami menyatakan kesiapannya dalam menyambut dan mendukung rencana pembangunan pariwisata tersebut. Hal ini terbukti dari beberapa kali kami menyampaikan ide tersebut, masyarakat yang hadir dalam pertemuan tersebut, secara kompak dan bulat menyatakan persetujuannya..." (Hasil wawancara 25 Februari 2016).
\end{abstract}

\begin{abstract}
"Since the beginning of the delivery of information on planning for proposing tourism development in Pakraman Jasri Village by the administrators of Desa Pakraman Jasri, the local community was very happy and welcomed the idea with great enthusiasm. Our community expressed their readiness to welcome and support the tourism development plan. The evident could be seen from several times we conveyed the idea, the people who attended the meeting, unanimously declared their consent ... "(Interview result February 25, 2016).
\end{abstract}

From the statement of I Ketut Kertia (62 years old) above, it can be seen that the enthusiasm of the local community seemed very high when they heard the idea of development and tourism development in Pakraman Jasri Village. This was understandable because when hearing the word tourism, people have imagined the euphoria, that the atmosphere of their village will be crowded with tourist visits, both domestic tourists, and foreign tourists. The local people have heard the condition of the area around the village of Pakraman Jasri which was first developed as a tourist destination, such as Taman Ujung, Tirta Gangga Park, Tenganan Village, and some other villages in Karangasem regency.

The role of the local community in the early planning of Jasri Tourism Village was (a) the commitment and the community support; (b) maintaining the cleanliness and the environment, (c) improving the quality of human resources; and (d) exploring the potential of local tourism.

\subsubsection{The Role of the Local Community in the Development of Jasri Tourism Village}

After almost has been two years old was considered as a period of planning, since then 2011, the stage of tourism development in the Pakraman Jasri Village began to be done. The role of the community in the development of tourism in this village was increasing. This evidence can be seen from the various efforts that have been done by the village community Pakraman Jasri. Here, the detailed role of the local community in the development of the Tourism Village of Jasri, namely (a) provide supporting tourism facilities; (b) establish supporting institutions of tourism; (c) introduce and publish Jasri tourism potential.

\subsection{The Role of the Government}

As a part of tourism stakeholders, the role of government, especially the government of Karangasem Regency and its subordinates, such as the Culture and Tourism Department that overshadowed the tourism sector, the sub-district government, to the village / kelurahan level in Karangasem regency determines the success of a tourist destination where the development of tourism was done. Based on data obtained in the field, it is known that the role of government in the development of Desa Pakraman Jasri as a tourist village can be explained as follows.

\subsubsection{The Role of the Government In the Early Planning of Jasri Tourism Village}

The local government of Karangasem Regency as one of the tourism stakeholders in this village has made various efforts in order to support the success of planning to develop the tourism in the Village of Pakraman Jasri.

The local government has provided a number of funds that can be managed and utilized by the community as a capital of economic development in the villages. The economic development in a village, of course adjusted to the potential of each village. Through this program, villagers are

Suniastha Amerta, I. M. (2017). The role of tourism stakeholders at Jasri tourism village development, Karangasem regency. International Journal of Social Sciences and Humanities, 1(2), 20-28. https://doi.org/10.29332/ijssh.v1n2.32 
welcomed to submit proposals for the use of "PNPM Mandiri" funds. This was conveyed by an informant named Made Sosiawan (53 years old) the Secretary of Culture and Tourism Office of Karangasem Regency.

\begin{abstract}
“...kami dari Dinas Kebudayaan dan Pariwisata Kabupaten Karangasem hanya membreak down program pemerintah pusat melalui program "PNPM mandiri" yang digulirkan setiap tahun kepada masyarakat desa. Masyarakat, melalui perangkat desa masing-masing dapat mengusulkan berbagai program yang berhubungan dengan pembangunan dan peningkatan perekonomian desa. Hal ini juga dilakukan oleh masyarakat Desa Pakraman Jasri, Kelurahan Subagan, yang saat itu mengusulkan pembangunan dan pengembangan desa wisata"(Hasil wawancara 25 Februari 2016).

“...We from the Department of Culture and Tourism of Karangasem Regency only break down the central government program through the "PNPM Mandiri" program that was rolled out annually to the village community. The local communities, through their village apparatus, can propose various programs related to the development and improvement of the village's economy. This was also done by the villagers of Pakraman Jasri Village, Subagan Sub-District, who at that time proposed the development and development of the tourist village "(Interview result of February 25, 2016).
\end{abstract}

Based on the statement made by Made Sosiawan above, it can be seen that the Government of Karangasem Regency has conducted socialization on various programs that are scheduled by the central government. One of them is the National Community Empowerment Program (PNPM Mandiri). Through this program, the central government wants to involve and empower the community in rural development by rolling aid funds to villages in Indonesia. The community can apply for those funds by making proposals of activities and suggesting various programs of activities that lead the local community empowerment and improving the economy of rural communities. When their proposal is approved, the public receives a grant from the central government. This opportunity was captured by the local community of Jasri Village which has various tourism potential in the village which is feasible to be developed. However, the role of government in the early planning of the Tourism Village of Jasri can be divided into (a) dissemination the program of "PNPM Mandiri"; (b) to provide guidance to the public.

\title{
3.2.2 The Role of the Government in the Development of Jasri Tourism Village
}

The process of tourism development in Jasri Village has been done since 2011. The development of tourism in Pakraman Jasri village began to look stretched in 2013. The most prestigious achievement as the best national tourism village in 2013 was achieved by Jasri Tourism Village by setting aside 138 villages from 29 provinces in Indonesia. What an exciting and pride achievement, not only for the people of Pakraman Jasri Village only but also for the Government of Karangasem Regency as well as the Government of Bali Province. However, the role of government in the development phase of Jasri Tourism Village shortly can be divided into (a) to legitimate the Tourism Village of Jasri; (b) to provide guidance, assistance, and promotion.

\subsection{The Role of the Tourism Actors (investors)}

The existence of alternative tourism development in the form of tourism village in Jasri Village can not be separated from the role of tourism actors (investors) from Jasri Village. In this writing, tourism actors (investors) defined as those who have activities in the field of tourism and make direct contact with tourists. The tourism actors (investors) as a part of tourism stakeholders play an important role either in the early planning or in the phase of the development of Jasri Tourism Village.

\subsubsection{The Role of the Tourism Actors (investors) in the Early Planning of Jasri Tourism Village}

As one of the tourism stakeholders, the role of tourism actors (investors) in Pakraman Jasri Village since the early tourism planning development in this village has been felt by the local 
community. In the beginning, the villagers of Desa Pakraman Jasri were not interested, even they were apathetic towards tourism. This was because they have not understood the importance of tourism development for the community yet.

The important role of tourism stakeholders from the tourism actors (investors) elements delivered by I Ketut Loka (66 years old), a head of Banjar Semadi, Jasri Kelod.

\begin{abstract}
“...rencana pembangunan pariwisata di Desa Pakraman Jasri mendapat respons yang positif dari pengurus desa dan masyarakat setempat, selain karena berbagai potensi wisata yang dimiliki desa Jasri seperti pemandangan laut yang indah, beragamnya kesenian sakral, termasuk potensi SDM yang punya skill dalam bidang pariwisata, juga karena adanya masukan-masukan dan motivasi yang diberikan oleh tokoh masyarakat yang sudah lebih dulu terjun di dunia pariwisata" (Hasil wawancara, 24 Januari 2016).

“... the planning on the tourism development in Pakraman Jasri Village got a positive response from the local community. In the other hand, Jasri Village also has the various tourism potentials such as beautiful sea views, sacred arts, including the potential of human resources who have skills in tourism. Some inputs and motivations were also given by the tourism actors figure who had already been involved in the world of tourism" (Interview result on January 24, 2016).
\end{abstract}

The opinion given by Ketut Loka above describes a positive response shown by the local public figure and by the local community on the development of tourism in Jasri Village. This also happens due to the tourism potential factor owned by Pakraman Jasri Village. In addition, the local community gets various inputs in the form of motivation given by local tourism actors who already have experience in the world of tourism. However, the role of tourism actors (investors) in the early planning of the Tourism Village of Jasri, can be concluded as (a) proposing the idea of tourism development in Pakraman Village of Jasri; (b) giving motivation, and (c) preparing accommodation.

\title{
3.3.2 The Role of the Tourism Actors (investors) in the Development of Jasri Tourism Village
}

As a form of moral responsibility in the development of alternative tourism in Jasri Tourism Village, the tourism actors (investors) in this village have done some strategic steps. The steps in which were expected to support tourism development in this tourism village. Those steps are: (a) to promote the Village Tourism of Jasri; (b) providing feedback of innovative new tourist attractions.

\section{Conclusions}

The establishment and development of alternative tourism in the form of tourism village of Jasri since the early planning stage until its development was truly supported by the local community of the Pakraman Village of Jasri, the local tourism actors (investors), and also by the Government of Karangasem Regency. Each part of the tourism stakeholders in the village has done their efforts in supporting the development of Jasri Tourism Village.

The efforts that have done by the local community of Jasri Village such as (a) the commitment and the community support; (b) maintaining the cleanliness and the environment, (c) improving the quality of human resources; and (d) exploring the potential of local tourism; (e) provide supporting tourism facilities; (f) establish supporting institutions of tourism; and (g) introduce and publish Jasri tourism potential.

Some steps done by the Government of Karangasem Regency were: (a) dissemination the program of "PNPM Mandiri"; (b) to provide guidance to the public; (c) to legitimate the Tourism Village of Jasri; and (d) to provide guidance, assistance, and promotion.

However, the local tourism actors (investors) of Jasri Village has also played important role, such as (a) proposing the idea of tourism development in Pakraman Village of Jasri; (b) giving motivation; and (c) preparing accommodation; (d) to promote the Village Tourism of Jasri; and (e) providing feedback of innovative new tourist attractions.

Suniastha Amerta, I. M. (2017). The role of tourism stakeholders at Jasri tourism village development, Karangasem regency. International Journal of Social Sciences and Humanities, 1(2), 20-28. https://doi.org/10.29332/ijssh.v1n2.32 
All of those steps were done by the tourism stakeholders in Jasri Village to make sure that the development of Jasri Tourism Village will be a successful and able to give a significant impact, particularly in improving the welfare of the local society of the Pakraman Village of Jasri in the future time.

\section{Acknowledgement}

The author would like to thank and deliver a high appreciation to the Rector of Warmadewa University and the Dean of Faculty of Economics of Warmadewa University. Thank are also referred to the Head of Management Study Program Warmadewa University for any facility that has been given to the author. The last but not least, thanks as well as extended to the informants, particularly, in Pakraman Jasri Village. 


\section{References}

Adetunji, A. T., Adetunji, A. V., Adeleke, E. O., \& Madubuike, S. C. (2017). Deregulation: The Effect of Market-led Approach to Nigerian Universities Management. International Journal of Social Sciences and Humanities (IJSSH), 1(1), 1-8.

Adhisakti, Laretna T. 2000. "Strategy of Tourism Village Development in Indonesia," National Seminar on Community Based Tourism Empowerment Empowerment in welcoming the Regional Autonomy of Bali. Denpasar: Udayana University.

Agung, A.A. Putra. 2009. "Membangun Karangasem dari Aspek Sosial Budaya," dalam Nyoman Suparta, I Nyoman Rai, Gede S. Surya Kusuma (ed.), Building Strategy Karangasem. Denpasar: Pustaka Nayottama.

Amerta, I. M. S. (2017). The Role of Tourism Stakeholders at Jasri Tourism Village Development, Karangasem Regency. International Journal of Social Sciences and Humanities (IJSSH), 1(2), 20-28.

Ardika, I Wayan. 2003. "Components of Bali Culture as a Tourist Attraction "in Ardika (editor), Sustainable Cultural Tourism Reflection and Hope in the Middle of Global Development. Denpasar: Master Program (S2) of Tourism Studies of Udayana University.

Astawa, I. N., Mantra, I. B. N., \& Widiastuti, I. A. M. S. (2017). Developing Communicative English Language Tests for Tourism Vocational High School Students. International Journal of Social Sciences and Humanities (IJSSH), 1(2), 58-64.

Barker, Chris. 2005. Cultural Studies Teori \& Praktik. Yogyakarta: PT Bentang Pustaka. [Google Scholar]

Basak, A., \& Khanna, K. (2017). A Study on the Selection Criteria of Different Hotels of Delhi NCR in Accordance to the HR Policies and Market Trends. International Journal of Social Sciences and Humanities (IJSSH), 1(1), 27-38.

Billaiya, R., Malaiya, S., \& Parihar, K. S. (2017). Impact of Socio Economic Trends on Students in Quality Education System. International Journal of Social Sciences and Humanities (IJSSH), 1(1), 16-20.

Cedeño, M. L. D., Arteaga, M. G. D., Pérez, A. V., \& Arteaga, M. L. D. (2017). Regulatory Framework for Renewable Energy Sources in Ecuador Case Study Province of Manabí. International Journal of Social Sciences and Humanities (IJSSH), 1(2), 29-42.

Cooper, Christ. 2005. Tourism Principles and Practice. England: Pearsen Education Limited.

Endraswara, Suwardi. 2006. Methods, Theories, Techniques of Cultural Research: Ideology, Epistemology, and Applications. Yogyakarta: Pustaka Widyatama.

Gámez, M. R., Pérez, A. V., Será, A. S., \& Ronquillo, Z. M. (2017). Renewable Energy Sources and Local Development. International Journal of Social Sciences and Humanities (IJSSH), 1(2), 10 19.

Ghosh, C. (2017). A Study on-Evaluating Marketing Strategies Adopted by Home Appliance for Economic Development in India. International Journal of Social Sciences and Humanities (IJSSH), 1(1), 9-15.

Inskeep, Edward. 1991. Tourism Planning In Intergrated and Sustainable Development. Osaka Japan: APTEK.

Maba, W. (2017). Teacher's Perception on the Implementation of the Assessment Process in 2013 Curriculum. International Journal of Social Sciences and Humanities (IJSSH), 1(2), 1-9.

Maba, W., \& Mantra, I. B. N. (2017). An Analysis of Assessment Models Employed by The Indonesian Elementary School Teachers. International Journal of Social Sciences and Humanities (IJSSH), 1(1), 39-45.

Muller, Dieter K. dan Pettersson, Robert. 2005. "What and Where is the Indigenous at an Indigenous Festival?-Observations from the Winter Festival in Jokkmokk, Sweden," dalam Ryan, Chris and Aicken, Michelle (eds.) Indigenous Tourism: The Commodification and Management of Culture. Amsterdam, The Netherland: Elsevier.

Pilliang, Y.A. 2004. The Folded World: Sightseeing Transcends Cultural Boundaries. Bandung: Publisher: Jalasutra.

Suniastha Amerta, I. M. (2017). The role of tourism stakeholders at Jasri tourism village development, Karangasem regency. International Journal of Social Sciences and Humanities, 1(2), 20-28. 
Strauss, Anselm, Yuliet Corbin. 2003. Qualitative Research Basics, Steps and Technical Techniques Data Theorizing (Translation). Yogyakarta: Pustaka Pelajar.

Sudikan, S.Y. 2000. Cultural Research Methods. Surabaya: Citra Wacana.

Sugiono. 2006. Bali Poverty Reduction Report. Denpasar: Bali Poverty Reduction Team.

Sugiono. 2008. Quantitative Research Methods, Qualitative, and R \& D. Bandung: CV Alfabeta.

Sugiono. www.google.com. Alternative Tourism. Downloaded August 15, 2015.

Suparsa, I. N., Mantra, I. B. N., \& Widiastuti, I. A. M. S. (2017). Developing Learning Methods of Indonesian as a Foreign Language. International Journal of Social Sciences and Humanities (IJSSH), 1(2), 51-57.

Suryasa, I. W., Prayoga, I. G. P. A., \& Werdistira, I. W. A. (2017). An Analysis of Students' Motivation Toward English Learning As Second Language Among Students In Pritchard English Academy (PEACE). International Journal of Social Sciences and Humanities (IJSSH), $1(2), 43-50$.

Suwantoro, Gamal. 1997. Planning a tourist product. Yogyakarta: Diparda.

\section{Biography of Author}

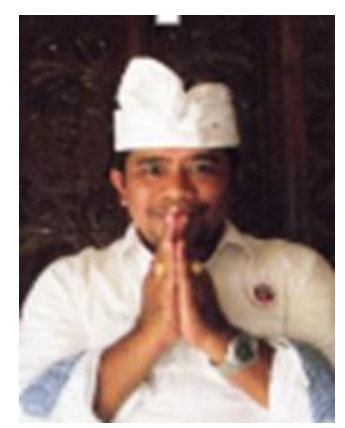

I Made Suniastha Amerta, is a senior lecturer at the Management study program, Faculty of Economics, Warmadewa University, Denpasar. E-mail address: jrokadek@yahoo.co.id and phone number 081805533605; 082145990998. The last education is the Doctorate of Cultural Studies Program, Udayana University Denpasar. He has completed his Bachelor academic at English Department Study Program, Faculty of Letters Warmadewa University in 1998 and Master of Tourism in Tourism Studies Program, Udayana University in 2005. He is interested in doing the research on the cultural tourism and management field. 